\title{
William Henry Bragg
}

\section{2-1942}

\section{Man and Scientist}

\section{G. M. CAROE}

Sir William (Henry) Bragg and his son Sir (William) Lawrence Bragg were the first to explore the structure of crystals using X-ray diffraction techniques, and their work was recognised by a shared Nobel Prize in 1915. This biography of the elder Bragg is written by his daughter for the general reader and tells the life story of an eminent scientist who became a spokesman for science during the first half of this century.

68.95 net

\section{Paperback edition}

\section{Introduction to Newton's 'Principia'}

\section{BERNARD COHEN}

This introduction to Isaac Newton's great work on mathematical physics was first published in 1971 as a prologue to the new edition of the Principia edited by Alexandre Koyré and I. Bernard Cohen. It describes the writing and first publication of the book, gives an analytical history of the changes made in its various editions, and discusses the critical reception to the several editions.

\section{An Introduction to the History of Virology A. P. WATERSON and LISE WILKINSON}

This book describes the development of knowledge about the study of viruses, and the diseases which they cause in plants, animals and man. The authors have attempted in the book to see viruses through the eyes of those experimenting with them at the time. It is essentially the story of ideas and of their origins, and of the formulation and development of the virus concept to its present-day clarity.

$\$ 12.00$ net

\section{Man and Nature in the Renaissance}

\section{A. G. DEBUS}

An integrated introduction to science and medicine from the mid-fifteenth to the mid-seventeenth century. The book is illustrated with many beautiful, contemporary pictures and is suitable for undergraduate students taking courses in the history of science, and general readers with an interest in this area. Cambridge History of Science Series Publication November

\section{CAMBRIDGE UNIVERSITY PRESS}


HISTORICAL STUDIES

\section{IN THE PHYSICAL SCIENCES}

\section{Volume Eight}

\section{Edited by Russell McCormmach and Lewis Pyenson}

Devoted to articles on the development of the physical sciences from the 18 th century to the present, this prestigious series has come to be described as "the publication of choice" in the history of science. The eighth annual volume takes as its central theme the birth and consolidation of new sciences in the period 1800-1940. With this volume The Johns Hopkins University Press assumes publication of this distinguished series.

\section{Contents}

Temple to Science: Cooperative Research and the Birth of the California Institute of Technology-Robert H. Kargon. J. B. Biot and the Mathematization of Experimental Physics in Napoleonic France-Eugene Frankel. The Creation of a New Science: Joseph Fourier's Analytical Theory of Heat-Robert Marc Friedman. William Thomson and the Mathematization of Faraday's Electrostatics-Jed Z. Buchwall. Heisenburg, Models, and the Rise of Matrix Mechanics-Edward MacKinnon. Unmechanischer Zwang: Pauli, Heisenberg, and the Rejection of the Mechanical Atom, 1923-1925Daniel Serwer. Rudolf Schoenheimer, Isotopic Tracers, and Biochemistry in the 1930's -Robert E. Kohler, Jr.

344 pages, $£ 14.00$

\section{STUDIES IN THE HISTORY OF BIOLOGY Volume One}

\section{Edited by William Coleman and Camille Limoges}

This is the first volume of an annual series to be devoted to the history of the biological sciences. Each volume will contain original, scholarly articles, of up to 25,000 words, critical review essays on recently published books or groups of books, and occasional historiographical or methodological essays.

\section{Contents}

The Gene as Catalyst: The Gene as Organism-Arnold Ravin. Experiment and Explanation in the Physiology of Bichat and Magendie-William Randall Albury. Nature and Nurture: The Interplay of Biology and Politics in the Work of Francis GaltonRuth Schwartz Cowan. Conceptual History: A Review of Francois Jacob, La Logique du Vivant-Frederic J. Holmes.

256 pages, $f 11.20$

\section{THE DOUBLE FACE OF JANUS AND OTHER ESSAYS IN, THE HISTORY OF MEDICINE}

\section{Owsei Temkin, M.D.}

Pre-eminent historian of medicine, Owsei Temkin has brought to his writing over the past forty years an awesome range of scholarship, for he is at home in the classical, the medieval, and the modern eras. This collection brings together in one volume nearly all the essays Temkin considers most important. They have been widely commended for their originality and intelligent analysis. 592 pages, 118.00

\section{Johns Hopkins University Press 2-4 Brook St., London W1}

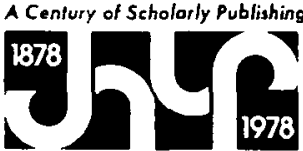




\section{The Young Darwin and His Cultural Circle}

A study of influences which helped shape the language and logic of the first drafts of the theory of natural selection

\section{bY EDWARD MANIER}

1978, xiv+237 pp.+index

Cloth DfI. 65,-/ US \$24.50 ISBN 90-277-0856-8

Paper DfI. 30,- / US \$11.95 ISBN 90-277-0857-6

STUDIES IN THE HISTORY OF MODERN SCIENCE 2

Based on notebooks, manuscripts and marginalia dating from 1837-44, this book probes the significance of a set of influences overlooked until now: the young Darwin's sympathetic reading of William Wordsworth's The Excursion, his notebook comments on Dugald Stewart's realistics philosophy of sign and metaphor: his intense reaction to Brewster's lengthy review of August Comte's Cours de Philosophie Positive, and his critical review of Sir James Mackintosh's Dissertation on the Progress of Ethical Philosophy. It shows how this manuscript evidence is at odds with established scholarly opinion concerning the logical structure of Darwin's theory, his exploitation of the scientific uses of metaphor to represent the role of chance in evolution, his 'materialism', his religious and aesthetic attitutes and the ethical implications of natural selection.

\section{New Perspectives on Galileo}

Papers Deriving from and Related to a Workshop on Galileo held at Virginia Polytechnic Institute and State University, 1975.

odited by ROBERT E. BUTTS and JOSEPH C. PITT

1978, xvit257 pp.+index

Cloth Dfl. 75,--/ US \$29.50 ISBN 90-277-0859-2

Paper Dfl. 30,- / US \$ 12.50 ISBN 90-277-0891-6

WESTERN ONTARIO SERIES 14

Galileo is generally acknowledged to be a crucial figure in the scientific revolution of the 16th and 17 th centuries. However, his thought was much too complex, much too original in some aspects and yet much too dependent upon earlier modes of enquiry to make the task of reconstructing his philosophy of science easy. No catalogue of historical details can perform this task, neither will a systematic presentation by philosophers of the 'logic' of his methodology succeed. The papers presented here grew out of an interdisciplinary workshop on Galileo held in 1975. They are not the proceedings, but rather the revised result of interdisciplinary stimulation between philosophers and historians. As such, the book succeeds in reflecting and integrating not just one or two but many of the dimensions of this seminal thinker in the development of modern science. 


\section{The British Society for the History of Science}

LiKe the discipline which it represents, the British Society for the History of Science has grown considerably since its foundation in 1947. The object of the Society is to further the discipline in all possible ways, particularly by holding meetings for the reading and discussion of papers, and by publication of relevant material. The Society offers a forum for all who have an interest in the history of science; although it is based in Britain, its membership is international. It welcomes applications for membership from students as well as established scholars, and from non-specialists as well as professional historians of science.

Membership of the Society, which includes a subscription to The British journal for the history of science, is open to all persons approved by the Council of the Society and elected at an ordinary meeting (formalities required by the UK Companies Act). The annual subscription is $£ 7.00$ (US \$21.00 in the Americas, Canada, and Japan) or, for students, $£ 3.00$ (\$9.00).

Applications for membership should be made on a form which is available from the Society's Administrator at the address below.

Meetings: The Society mounts an ambitious programme of meetings. The pattern is flexible, the only fixture being the three-day summer meeting, held at a different British university or polytechnic each year. About four other meetings, lasting for between one and three days, are held during the year, sometimes devoted to a clearly-defined theme or an important anniversary, and often arranged in conjunction with other scholarly societies.

The British Journal for the History of Science is the official organ of the Society. It is published three times a year, in March, July, and November, and the three parts constitute a volume. Articles and reviews range over all aspects of the history of science, and many are interdisciplinary in character, encompassing social and economic history, the philosophy and sociology of science, the history of technology, and the relations between science and theology. Contributions from members and non-members are welcomed alike.

Editorial matters: Papers for inclusion in the fournal should be submitted to the Editor, Dr Nicholas Fisher, Department of History and Philosophy of Science, King's College, Aberdeen $\mathrm{AB}_{9}{ }_{2} \mathrm{UB}$, Scotland, from whom instructions may be obtained concerning the presentation and documentation of papers. All correspondence on the content of the fournal, and all books for review, should be addressed to the Editor.

Advertising: Particulars about advertising in the fournal may be obtained from the Society's Administrator.

Orders and back issues: Orders for the fournal and inquiries about back issues should be addressed to the Administrator. Claims for missing copies should be made within six months of publication. The annual subscription for non-members is $\$ 12.00(\$ 30.00)$.

Other publications: BSHS Monograph Series is designed to allow the publication of monographic studies in the history of science quickly and cheaply. All correspondence on the subject of monographs, and any new suggestions for titles, should be sent to the Series Editor, Dr Roger Smith, Department of History, University of Lancaster, Bailrigg, Lancaster LAI 4 YG, England. Monographs are available to members at a discount of $25 \%$, post-free from the Society's Administrator. Non-members may obtain them through bookshops, or post-free from the Administrator.

Now available:

Images of the earth: essays in the history of the environmental sciences. Ed. by L. J. Jordanova and R. Porter.

List of theses: Every December, the Society publishes a full list of current theses in history of science in British universities. This is available free to members, and at a small charge to non-members, on request to the Administrator. Standing orders are accepted from members or non-members who wish to receive the list regularly.

All the administrative business of the Society is handled by

The Administrator, The British Society for the History of Science, Halfpenny Furze, Mill Lane, Chalfont St Giles, Bucks HP8 4 NR, England.

C. The British Society for the History of Science 1978 


\section{The British Journal}

\section{for the}

\section{History of Science}

November 1978

Volume XI Part 3 No 39

Richard D. McKirahan : Aristotle's Subordinate Sciences

$197-220$

Pietro Corsi: The Importance of French Transformist Ideas for the Second Volume of Lyell's Principles of Geology

$221-244$

DAvid BLOoR: Polyhedra and the Abominations of Leviticus

$245-272$

Essay Review:

EDWARD Yoxen: The History of Molecular Biology

273-279

Book Reviews

$280-296$

Books Received

297-299

Notes on Contributors

299

Report of Council

300-303

Published by

The British Society for the History of Science

Registered Office: Halfpenny Furze, Mill Lane, Chalfont St Giles, Bueks HP8 4NR

Price: $\$ 4.00$ or $\$ 12.00$ including postage (Free to members of the Society)

Brit. J. Hist. Sci. XI No 39* Published November 1978 